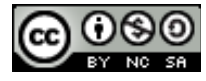

https://doi.org/10.31743/abmk.13131

\title{
FOTOGRAFIE ORGANÓW W ZBIORACH ARCHIWUM DIECEZJALNEGO W TARNOWIE JAKO ŹRÓDŁA DO DZIEJÓW ORGANÓW W DIECEZJI TARNOWSKIEJ
}

\begin{abstract}
Streszczenie
Fotografie organów w Archiwum Diecezjalnym w Tarnowie zachowały się głównie jako dodatek do ankiet Ośrodka Dokumentacji Zabytków z 1971 r. dotyczących stanu organów w parafiach. Artykuł omawia te $\mathrm{z}$ nich, które przedstawiają instrumenty dziś nieistniejące, przebudowane lub przeniesione do innych kościołów. Oprócz tych fotografii w archiwum znajdują się zaproszenia na poświęcenia pięciu instrumentów, także zawierające ich zdjęcia.
\end{abstract}

Słowa kluczowe: archiwum; organy; budownictwo organowe; diecezja tarnowska

$* * * * *$

Zdjęcia organów, jakie znajdują się w Archiwum Diecezjalnym w Tarnowie, związane są głównie z jednym przełomowym wydarzeniem, będącym wstępem do inwentaryzacji zabytkowych organów w Polsce. W latach 1970-1971 Ośrodek Dokumentacji Zabytków, w porozumieniu z Konferencją Episkopatu Polski, rozesłał do parafii za pośrednictwem kurii diecezjalnych ankietę, w której znalazły się pytania na temat historii i szczegółów technicznych organów znajdujących się w parafii, a także związanych z nimi dokumentów. Dołączono do niej prośbę o wykonanie zdjęć prospektu i stołu gry organów. Ankiety były wypełniane głównie przez proboszczów i organistów, a więc osoby nie zawsze kompetentne w przedmiocie sprawy, mimo to badanie mogło utworzyć obraz stanu organów na przeważającym obszarze Polski. Po wpłynięciu odesłanych ankiet do centrali Ośrodka Dokumentacji Zabytków jego pracownicy sporządzili ich odpisy, po

*Paweł Pasternak - dr sztuki

e-mail: pawel.pasternak@chopin.edu.pl

https://orcid.org/0000-0003-1024-2110 
czym oryginały zwrócono do kurii diecezjalnych. W większości diecezji ankiety uchodzą za zaginione, nieznane jest miejsce ich przechowywania, a jedyną pozostałością po nich są niekompletne odpisy przechowywane w Narodowym Instytucie Dziedzictwa, wykonane często z błędami. Inną sytuację zastano w diecezji tarnowskiej. Większość ankiet zachowała się w nienaruszonym stanie w Archiwum Diecezjalnym w Tarnowie, w zbiorze akt rzeczowych (sygn. ARz 119120) i jest udostępniana badaczom. Ankiety są bezcennym źródłem informacji do dziejów organów, a zwłaszcza te z nich, które zawierają zdjęcia i opisy instrumentów już nieistniejących albo przebudowanych, a także relacje z prac remontowych napisane przez naocznych świadków. Postanowiłem omówić właśnie te fotografie, które dostarczyły szczególnie ważnych informacji na temat dziejów organów - przedstawiają instrumenty już nieistniejące, przebudowane bądź przeniesione na inne miejsca.

\section{Organy wybudowane przed II wojną światową}

\section{Prace anonimowe}

\subsection{Ropczyce-Witkowice}

Woj. podkarpackie, pow. Ropczyce-Sędziszów Małopolski

Od 1992 r. diecezja rzeszowska, dekanat Ropczyce

W drewnianym kościele w Witkowicach w 1966 r. nowe organy zbudował Tadeusz Rajkowski z Włocławka. Wykorzystał on prospekt i niektóre piszczałki z poprzednich, prawdopodobnie pochodzących z początku XIX wieku organów. Fotografia z 1971 r. przedstawia wygląd instrumentu przed rozbudową kościoła, która miała miejsce trzy lata później. Dobudowano wówczas murowaną część mieszczącą główne wejście, kruchtę oraz nowy chór muzyczny. Nie wiadomo, kto przenosił instrument na nowe miejsce, aczkolwiek ze względu na niewielki upływ czasu od budowy, i zapewne obowiązującą jeszcze gwarancję, musiał być to budowniczy organów ${ }^{1}$.

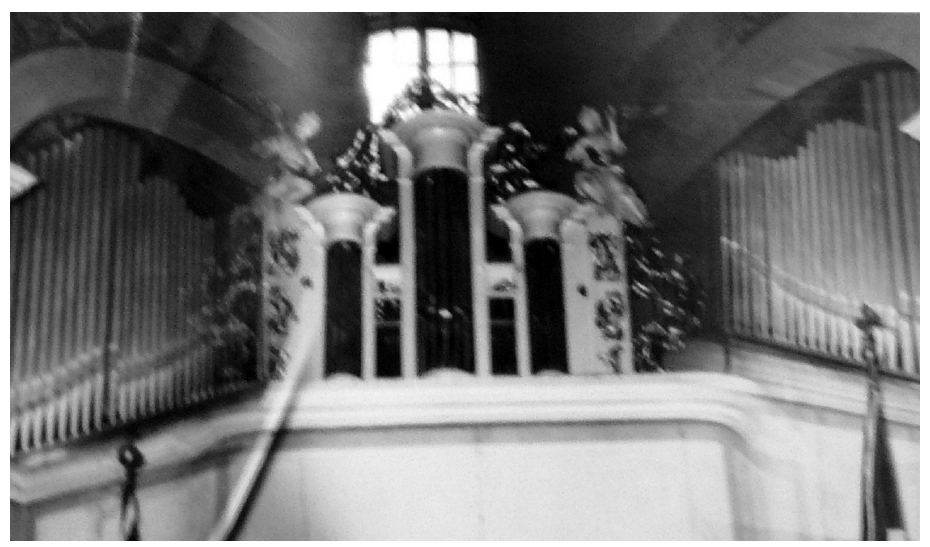

Il. 1. Prospekt organów w Ropczycach-Witkowicach w 1971 r. - fot. ADT

\footnotetext{
${ }^{1}$ P. Pasternak, Tadeusz Rajkowski. Działalność organmistrzowska, Opole 2021, s. 50-51.
} 


\subsection{Siedlce}

Woj. małopolskie, pow. Nowy Sącz

Diecezja tarnowska, dekanat Nowy Sącz-Centrum

Instrument $\mathrm{z}$ jednym manuałem i pedałem, wykonany zapewne $\mathrm{w}$ drugiej połowie XIX wieku dla poprzedniego, drewnianego kościoła, przeniesiono do nowej świątyni zbudowanej w $1901 \mathrm{r}$. Istniał tam najpewniej do lat 80. lub 90. XX wie$\mathrm{ku}$, po czym zastąpiono go instrumentem elektronicznym. Szczęśliwie zachowały się fotografie obiektu, przedstawiające prospekt i stół gry. Na takiej podstawie można stwierdzić, że organy miały trakturę mechaniczną, wiatrownice były zapewne klapowo-zasuwowe, a klawiatury miały zakresy: $\mathrm{C}-\mathrm{c}^{3} \mathrm{w}$ manuale oraz $\mathrm{C}-\mathrm{c}$ w pedale ${ }^{2}$.

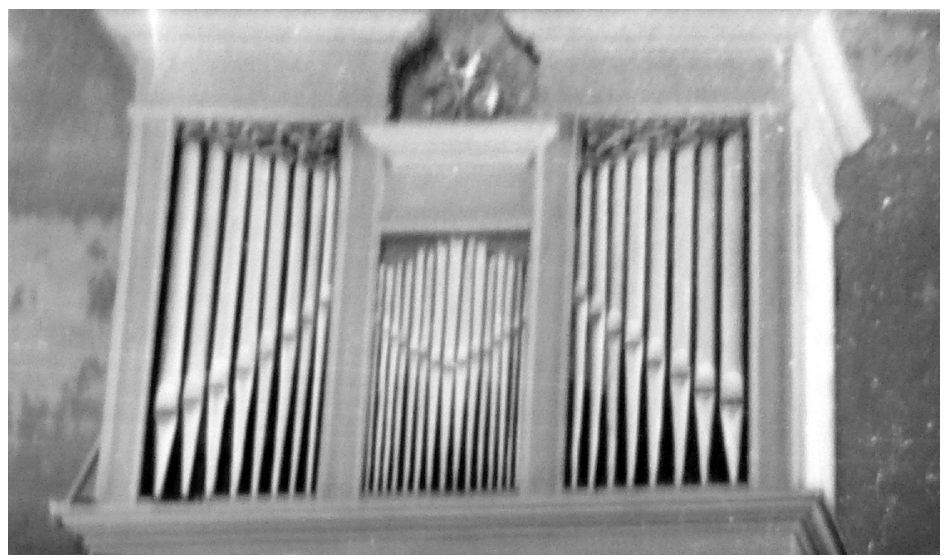

Il. 2. Prospekt organów w Siedlcach w 1971 r. - fot. ADT

\subsection{Strzelce Wielkie}

Woj. małopolskie, pow. Brzesko

Diecezja tarnowska, dekanat Uście Solne

Stary, drewniany kościół parafialny w Strzelcach Wielkich posiadał zbudowane w 1788 r. organy, z których zachował się prospekt. W 1977 r. Henryk Siedlar zbudował nowe, dwunastogłosowe organy o trakturze pneumatycznej, umieszczając je w starej szafie organowej. Stary instrument sprzedano do parafii Charsznica koło Miechowa w diecezji kieleckiej. Dnia 7 lipca 1978 r. tamtejszy proboszcz, ks. Ludwik Michalik, zawarł umowę na montaż z firmą Henryka Siedlara, mieszczącą się wówczas w Krakowie, w której organmistrz zobowiązał się zamontować instrument do Wielkanocy 1979 r. Miał on także dobudować klawiaturę pedałową o skali C-d ${ }^{1}$ z głosem Subbas 16'. W 2003 r. Jacek Siedlar, syn Henryka, kompletnie przebudował instrument w Charsznicy, skutkiem czego zachowane fotografie są jedynym świadectwem jego pierwotnego wyglądu³.

${ }^{2}$ Tamże, s. 58.

${ }^{3}$ P. Pasternak, Nowe instrumenty w diecezji tarnowskiej (2017), „Hosanna”, 13 (2018) nr 1(28), s. $30-31$. 


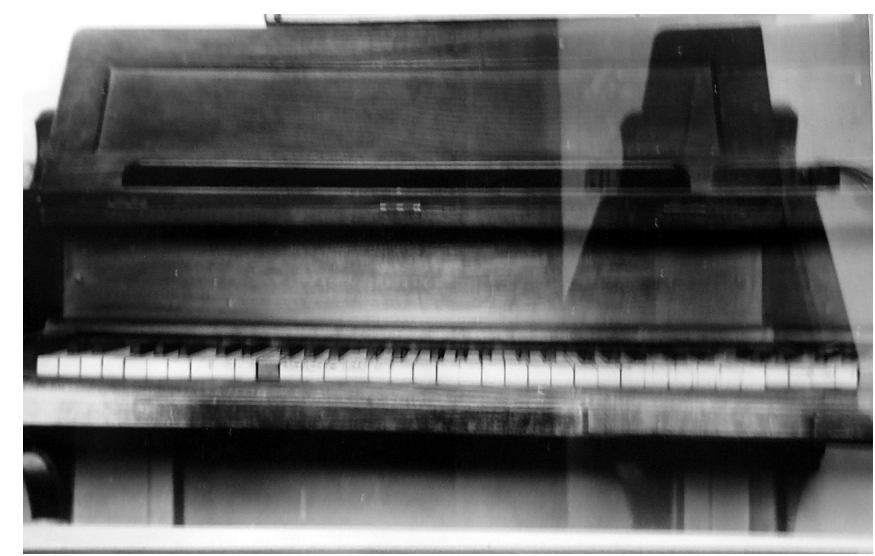

Il. 3. Stół gry organów w Strzelcach Wielkich w 1971 r. - fot. ADT

\section{Prace autorskie}

\section{Józef Baranowski - Stary Sącz}

\subsection{Zborowice}

Woj. małopolskie, pow. Tarnów

Diecezja tarnowska, dekanat Ciężkowice

Organy zostały zbudowane w 1865 r. Cechy stylistyczne wskazują na warsztat Józefa Baranowskiego ze Starego Sącza. Pierwotnie był to dziewięciogłosowy pozytyw. W 1959 r. rozbudowy dokonał Stanisław Czachor, organista z Tuchowa. Dodał on trzy głosy w manuale oraz dwugłosową sekcję pedału, zainstalował też dmuchawę elektryczną ${ }^{4}$. Dobudowane głosy miały trakturę pneumatyczną. Przed 2002 r. organy rozebrano, pozostawiając jedynie prospekt ${ }^{5}$.

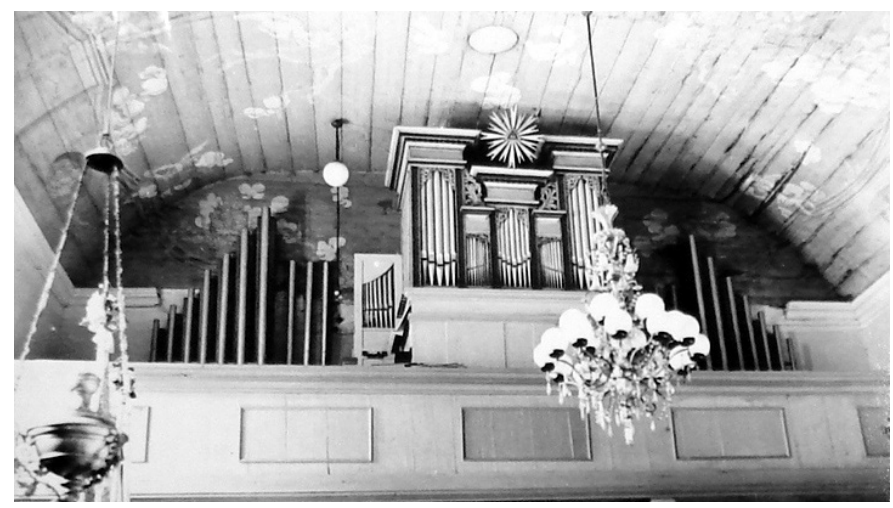

Il. 4. Prospekt organów w Zborowicach w 1971 r. - fot. ADT

${ }^{4}$ Archiwum Diecezjalne w Tarnowie (dalej: ADT), sygn. ARz 120, ankieta dotycząca organów (dalej: ADO) Zborowice z $1971 \mathrm{r}$.

${ }^{5}$ Archiwum Wydziału Muzyki Kościelnej kurii diecezjalnej w Tarnowie, bez sygn., Protokół przeglądu organów piszczałkowych w parafii Zborowice z 17 kwietnia $2002 \mathrm{r}$. 


\section{Tomasz Fall - Szczyrzyc}

\subsection{Czarna}

Woj. podkarpackie, pow. Dębica

Dekanat Dębica-Zachód

Kościół w stylu neogotyckim zbudowano tu w latach 1903-1906, z częściowym wykorzystaniem murów dawnego młyna. Okoliczności powstania w nim organów nie są do końca jasne. W ankiecie jako ich budowniczy wymieniany jest Andrzej vel Jędrzej Czerwiec, z odległej o pięć kilometrów Chotowej ${ }^{6}$. Zajmował się on głównie rzeźbą ${ }^{7}$ lecz także naprawą i strojeniem organów ${ }^{8}$. Instrument wykonany jest jednak w sposób typowy dla dzieł Tomasza Falla ze Szczyrzyca, znanego i zasłużonego dla diecezji tarnowskiej organmistrza ${ }^{9}$. Zdjęcia załączone do ankiety przedstawiają jeszcze pierwotny wygląd organów przed rozbudową kościoła, którą zaczęto trzy lata później. W 1974 r. dobudowano frontową część kościoła z nowym chórem muzycznym, co doprowadziło do znacznego zatarcia cech stylowych świątyni. Organy przeniesiono na nowy chór, gdzie funkcjonowały do ok. 2000 r. Po wyłączeniu ich z użytku postanowiono instrument sprzedać, jako niepasujący wielkością i wyglądem do obecnego wnętrza, zakupić zaś większe organy z Niemiec. Tak też się stało i stary instrument przeniesiono do bocznej kaplicy w Bazylice św. Mikołaja w Bochni. Tam jednak całkowicie zmieniono dekorację snycerską prospektu z neogotyckiej na neobarokową ${ }^{10}$. Prezentowana fotografia jest więc cennym świadectwem pierwotnego kształtu tych organów i może posłużyć ewentualnie ich przyszłej rekonstrukcji.

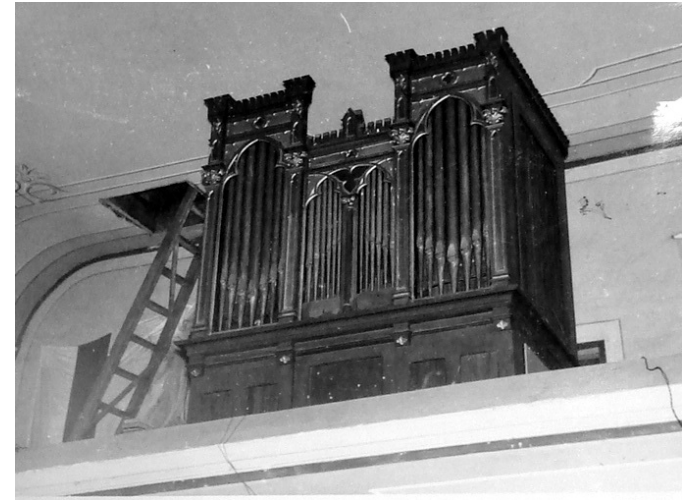

Il. 5. Prospekt organów w Czarnej w 1971 r. - fot. ADT

${ }^{6}$ ADT, sygn. ARz 119, ADO Czarna z $1971 \mathrm{r}$.

${ }^{7}$ A. Jedynak, Parafia wśród lasów, Tarnów 1990, s. 24.

${ }^{8}$ Skorowidz przemystowo-handlowy Królestwa Galicyi, red. J. Olszewski, Lwów 1912, szp. 505.

${ }^{9}$ Biograf Falla Ernest Kubala właśnie jemu przypisuje ten instrument. E. Kubala, Organmistrz Tomasz Fall (1860-1922). Życie i twórczość, Kraków 1984 [praca magisterska PWSM], s. 48.

${ }^{10} \mathrm{~K}$. Zwierniak, Organy w parafiach dekanatów Bochnia-Wschód i Bochnia-Zachód. Zarys historyczno-muzyczny, Kraków 2018 [praca magisterska napisana na Uniwersytecie Papieskim Jana Pawła II], s. 44-46. 


\subsection{Mogilno}

Woj. małopolskie, pow. Nowy Sącz

Dekanat Nowy Sącz-Wschód

Na fotografii z 1971 r. widoczne są organy Tomasza Falla z 1896 r., znajdujące się w starym kościele parafialnym. Nie istniał wówczas jeszcze nowy kościół, do którego przeniesiono instrument. Powstał on dopiero w 2005 r. ${ }^{11} \mathrm{~W} 2021 \mathrm{r}$. w nowym kościele zamontowano większe organy piszczałkowe sprowadzone z Holandii. Stary instrument natomiast planuje się przenieść z powrotem do starej świątyni.

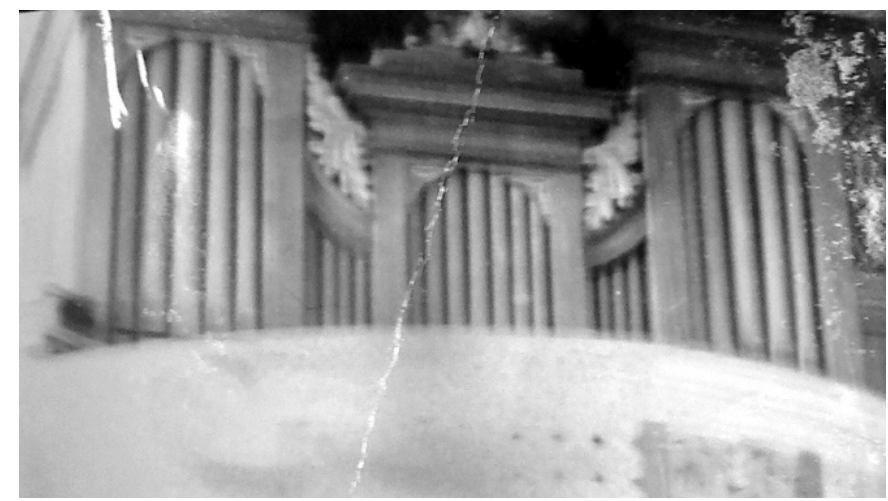

Il. 6. Prospekt organów w Mogilnie w 1971 r. - fot. ADT

\subsection{Mystków}

Woj. małopolskie, pow. Nowy Sącz

Dekanat Nowy Sącz-Wschód

Obecne organy zbudował Tomasz Fall ze Szczyrzyca w latach 1894-1895. Po zbudowaniu nowego kościoła w latach 1908-1910 przeniesiono do niego instrument, jednak był on za mały do nowego wnętrza. W 1964 r. zdecydowano się więc na jego rozbudowę, którą przeprowadził Stanisław Aleksander z Marcinkowic. Do istniejących dziewięciu głosów (siedmiu w manuale i dwóch w pedale) dobudowano trzygłosową sekcję manuału drugiego. Zdjęcie przedstawia dwumanuałowy stół gry wykonany właśnie na potrzeby tej rozbudowy. Obecnie instrument wygląda zupełnie inaczej, gdyż w 2008 r. był ponownie powiększany przez Mieczysława Ziemiańskiego ze Szczyrzyca ${ }^{12}$.

\footnotetext{
${ }^{11}$ P. Pasternak, Organy i ich twórcy na obszarze ziemi sądeckiej, Nowy Sącz 2018, s. 21-22.

${ }^{12}$ Tamże, s. 23-24.
} 


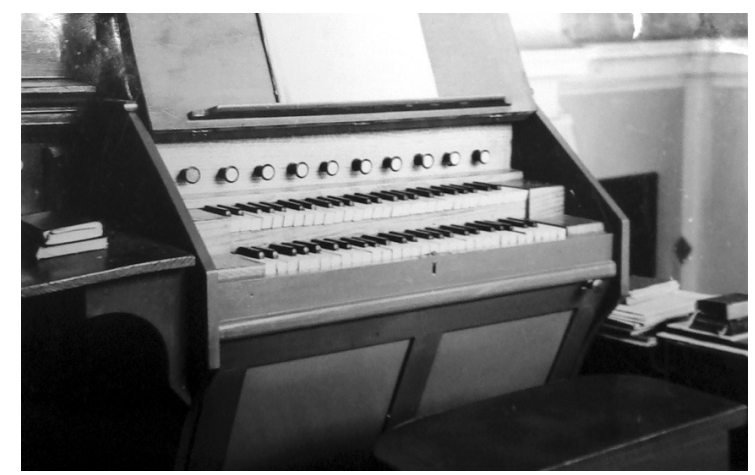

Il. 7. Stół gry organów w Mystkowie w 1971 r. - fot. ADT

\subsection{Nowy Sącz, kościół Najświętszego Serca Pana Jezusa}

Woj. małopolskie, pow. miejski Nowy Sącz

Dekanat Nowy Sącz-Wschód

Tutejsze organy to obiekt bardzo niejednorodny. Pierwsze wzmianki o istnieniu czterogłosowego instrumentu pochodzą z 1905 r. Kilkukrotnie prowadzono przy nim prace na szeroką skalę, o charakterze co najmniej przebudowy, a być może nawet budowy nowego obiektu z wykorzystaniem elementów istniejącego. Wykonywali je m.in. Tomasz Fall w 1921 r. i Bartłomiej Ziemiański w 1932 r. Największą z dotychczasowych modernizacji wykonano jednak w latach 19631964. Powiększono wtedy instrument z ośmiu do szesnastu głosów, trakturę zmieniono z mechanicznej na elektropneumatyczną, zainstalowano dwumanuałowy stół gry. Zachowane fotografie przedstawiają właśnie organy po tych pracach. Niedługo po ich wykonaniu przeszły jednak kolejną, jeszcze większą przebudowę, którą wykonał miejscowy organista Stanisław Wolak. Do 1981 r. dobudował on kolejnych czternaście głosów i sekcję manuału trzeciego. Zmienił także wygląd prospektu, do którego dorobiono też ruchome figury ${ }^{13}$.

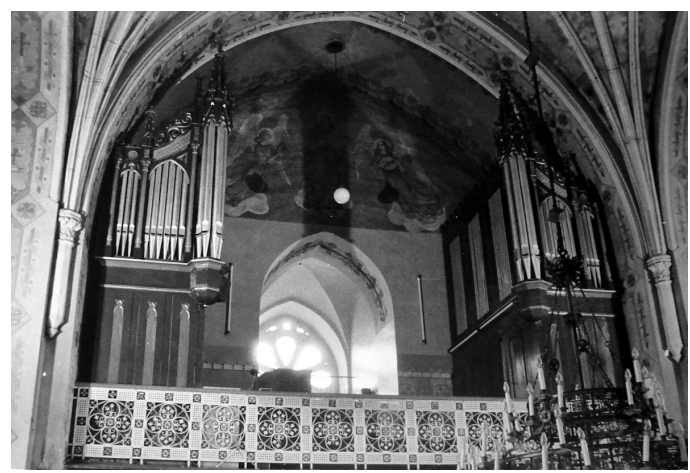

Il. 8. Prospekt organów w kościele NSPJ w Nowym Sączu w 1971 r. - fot. ADT

\footnotetext{
${ }^{13}$ Tamże, s. 34-37.
} 


\subsection{Pisarzowa}

Woj. małopolskie, pow. Limanowa

Dekanat Limanowa

Kościół wyposażony był w dziesięciogłosowe organy zbudowane w $1900 \mathrm{r}$. przez Tomasza Falla ze Szczyrzyca. Ich stan oryginalny został uwidoczniony na fotografiach w 1971 r., jednak około dziesięć lat później Stanisław Wilewski z Nockowej gruntownie przebudował instrument. Dyspozycja, z wyjątkiem jednego głosu, nie uległa zmianie, lecz zmieniono trakturę $\mathrm{z}$ mechanicznej na pneumatyczną, wiatrownice $\mathrm{z}$ klapowych na stożkowe oraz prospekt, zatem wygląd zewnętrzny organów jest dziś zupełnie inny. Oryginalna wiatrownica pedałowa została później wykorzystana przy przenoszeniu instrumentu Falla z Czarnej do Bochni (zob. p. 1.2.2), natomiast pozostałe części, jak prospekt i traktura manuałowa, trafiły do tworzonego muzeum Tomasza Falla w Szczyrzycu, gdzie na ich bazie ma być odtworzony wzorcowy instrument tego organmistrza ${ }^{14}$.

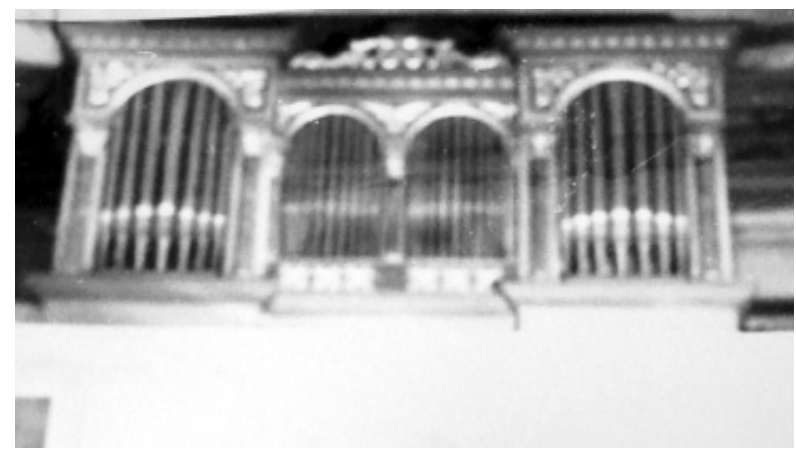

Il. 9. Prospekt organów w Pisarzowej w 1971 r. - fot. ADT]

\subsection{Zbyszyce}

Woj. małopolskie, pow. Nowy Sącz

Diecezja tarnowska, dekanat Nowy Sącz-Centrum

Prawdopodobnie w 1887 r. powstał nowy instrument, którego budowniczym był Tomasz Fall ze Szczyrzyca. Było to jedno z pierwszych dzieł tego organmistrza. W 2003 r. w kościele wybuchł pożar, w wyniku którego organy zostały zniszczone . Ocalałe części (stół gry, piszczałki drewniane i elementy traktury) zostały zdemontowane przez Kazimierza Plewę i złożone w parafialnym budynku gospodarczym ${ }^{15}$.

\footnotetext{
${ }^{14}$ Tamże, s. 433.

${ }^{15}$ Tamże, s. 60-61.
} 


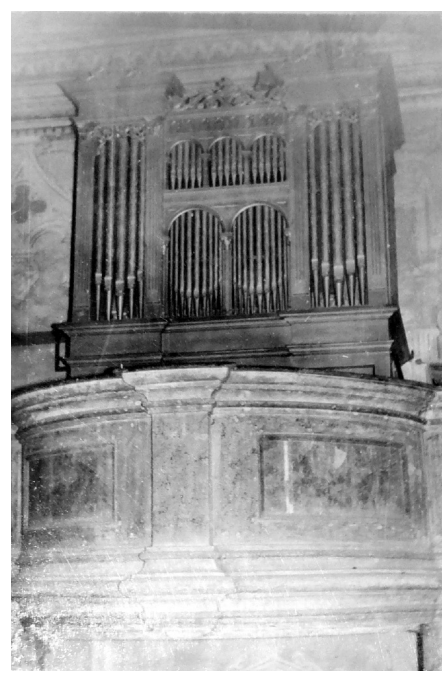

Il. 10. Prospekt organów w Zbyszycach w 1971 r. - fot. ADT

\section{8. Żabno}

Woj. małopolskie, pow. Tarnów

Diecezja tarnowska, dekanat Żabno

Prawdopodobnie w ramach odbudowy kościoła po pożarze z 1888 r. nowy instrument zbudował w 1892 r. wspomniany Tomasz Fall ze Szczyrzyca. Organy liczyły dziesięć głosów, jeden manuał i pedał, i miały trakturę mechaniczną. Fotografia z 1971 r. przedstawia ich prospekt. W 1979 r. planowano rozbudowę do dwudziestu pięciu głosów, której miał dokonać Stanisław Ziaja. Ostatecznie zdecydowano się zbudować całkiem nowe organy, czego dokonał Tadeusz Rajkowski z Włocławka w 1989 r. Obecnie znajduje się tu jeszcze inny instrument, sprowadzony w 2020 r. z Norwegii ${ }^{16}$.

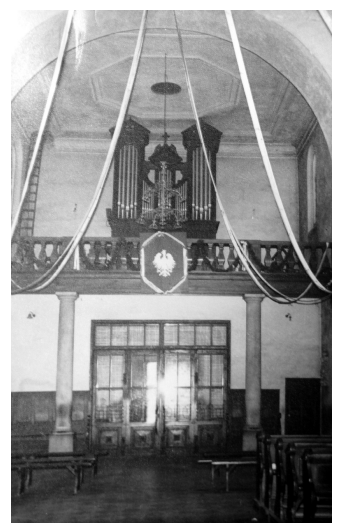

Il. 11. Prospekt organów w Żabnie w 1971 r. - fot. ADT

${ }^{16}$ P. Pasternak, Nowe instrumenty $w$ diecezji tarnowskiej (2020), „Hosanna”, 16 (2021) nr 2(35), s. 23-26. 


\section{Rudolf Haase - Lwów}

\subsection{Lubzina}

Woj. podkarpackie, pow. Ropczyce-Sędziszów Małopolski

Dekanat Pustków

Niemal w ostatniej chwili, bo kilka miesięcy przed rozbiórką, zostały udokumentowane pierwsze organy $\mathrm{w}$ tamtejszym kościele. Tak pisał wtedy o nich miejscowy proboszcz: „,(..) organy pneumatyczne 13-głosowe, wykonane przez Firmę Haase we Lwowie. Liczą dopiero 60 lat [w rzeczywistości z 1907], ale ciągle się psują, a są trudne do naprawienia, dlatego będą musiały być w najbliższym czasie przebudowane, a przy tej okazji powiększone o 7 nowych głosów" ${ }^{17}$. Prace te przeprowadził Stanisław Broszko. Oryginalny prospekt Haasego został w kuriozalny sposób odcięty i zawieszony nad balustradą chóru muzycznego, a za nim umiejscowiono drugi, właściwy, współczesny prospekt ${ }^{18}$.

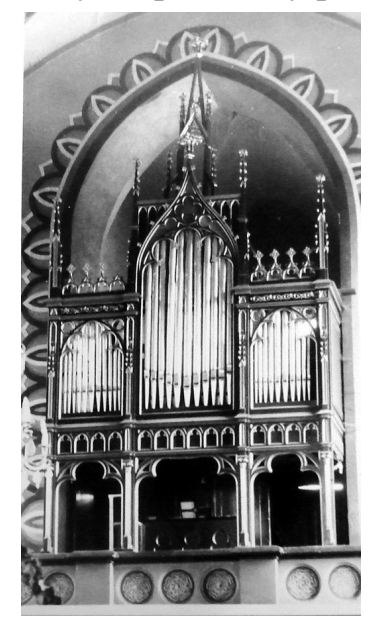

Il. 12. Prospekt organów w Lubzinie w 1971 r. - fot. ADT

\subsection{Ryglice}

Woj. małopolskie, pow. Tarnów

Diecezja tarnowska, dekanat Tuchów

Organy, które widzimy na zdjęciach, są znacznie przekształconym dziełem Rudolfa Haasego z ok. 1910 r. Instrument powstał dla dawnego, drewnianego kościoła, przeniesionego w 1947 r. do wsi Kowalowa. Przebudowa instrumentu miała związek z budową w latach 1928-1940 nowego, murowanego kościoła, a następnie translokacją organów na nowe miejsce. Powiększenia podjął się tuchowski organista Stanisław Czachor w 1957 r. Organy Haasego powiększo-

${ }^{17}$ ADT, sygn. ARz 119, ADO Lubzina z $1971 \mathrm{r}$.

${ }^{18}$ P. Pasternak, Kierunki stylistyczne $w$ budownictwie organowym $w$ diecezji tarnowskiej $w$ latach 1945-1992, t. 2, Warszawa 2021 [praca doktorska, Uniwersytet Muzyczny Fryderyka Chopina w Warszawie], s. 181-184. 
no z dwunastu do osiemnastu głosów, trakturę zmieniono na pneumatyczną, zainstalowano nowy prospekt i stół gry, widoczne na archiwalnych fotografiach. Przebudowa ta okazała się nieudana. W 1983 r. organy rozebrano, a nowe w ich miejsce postawił w 1992 r. Mieczysław Gwóźdź z Nowego Sącza ${ }^{19}$.

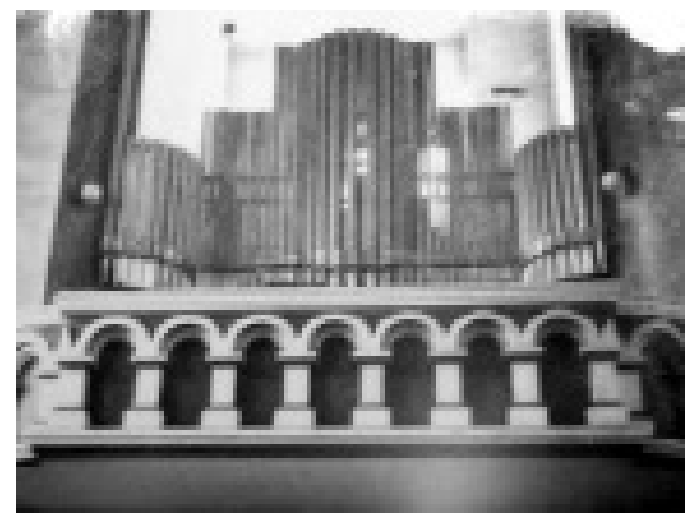

Il. 13. Prospekt organów w Ryglicach w 1971 r. - fot. ADT

\section{Mieczysław Janiszewski - Lwów}

\subsection{Piwniczna}

Woj. małopolskie, pow. Nowy Sącz

Dekanat Piwniczna

Organy dziewięciogłosowe zbudował tu w 1907 r. Mieczysław Janiszewski ze Lwowa, uczeń i kontynuator działalności znanego organmistrza lwowskiego Jana Śliwińskiego ${ }^{20}$. Jest to jego jedyna odnotowana praca na terenie diecezji tarnowskiej. Oryginalną dyspozycję i zdjęcie zawiera ankieta z $1971 \mathrm{r}^{21}$ Dziesięć lat później miała miejsce nieudana przebudowa, którą przeprowadził Stanisław Aleksander z Marcinkowic. Powiększył on organy do trzynastu głosów rozdzielonych na dwa manuały i pedał, przerobił także prospekt, w typowy dla siebie sposób zmieniając segmenty międzywieżowe. $Z$ powodu rażących nieprawidłowości konstrukcyjnych i niezgodności dyspozycji z faktycznym brzmieniem instrument nie został odebrany przez komisję diecezjalną. Kilkanaście lat później został on wyłączony z użytku i zastąpiony instrumentem elektronicznym. Obecnie stół gry nie istnieje $\mathrm{e}^{22}$, zachowana fotografia jest zatem jedynym świadectwem oryginalnego wyglądu tych organów.

\footnotetext{
${ }^{19}$ Tamże, s. 154-155, 411-413.

${ }^{20}$ M. Babnis, Kultura organowa Galicji ze szczególnym uwzględnieniem działalności organmistrza lwowskiego Jana Śliwińskiego, Słupsk 2012, s. 377-378.

${ }^{21}$ ADT, sygn. ARz 120, ADO Piwniczna z $1971 \mathrm{r}$.

${ }^{22}$ Pasternak, Kierunki stylistyczne, s. 380.
} 


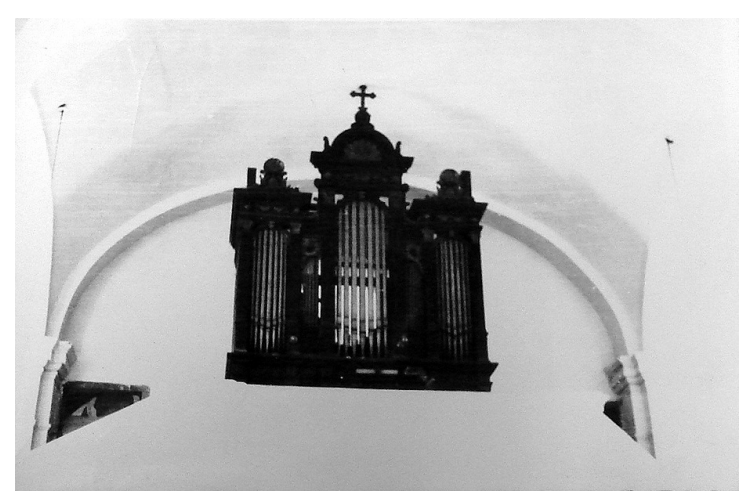

Il. 14. Prospekt organów w Piwnicznej w 1971 r. fot. ADT

\section{Gebrüder Rieger - Jägerndorf}

\subsection{Góra Ropczycka}

Woj. podkarpackie, pow. Ropczyce-Sędziszów Małopolski

Od 1992 r. diecezja rzeszowska, dekanat Sędziszów Małopolski

W 1909 r. znana śląska firma Rieger postawiła tu ośmiogłosowe organy jako opus (dzieło) $1574^{23}$. W parafii istniał wtedy drewniany kościół. Gdy niedługo później świątynia zaczęła się chylić ku upadkowi, w 1931 r. wybudowano tymczasowy barak, do którego przeniesiono wyposażenie kościoła wraz z organami. Podobnie uczyniono po zbudowaniu w latach 1949-1952 docelowej świątyni. Było to jednak rozwiązanie tymczasowe, ponieważ nowy kościół był dużo większy. Właśnie z tego okresu dysponujemy zdjęciami, które dają nam wyobrażenie o pierwotnym wyglądzie organów. W latach 80 . postanowiono o budowie nowego instrumentu, który w 1986 r. wykonał Mieczysław Gwóźdź z Nowego Sącza. Zachowano jednak stary prospekt Riegera, nieznacznie go rozbudowując. Dodano segmenty międzywieżowe ${ }^{24}$, co potwierdza porównanie fotografii dawnej i obecnej.

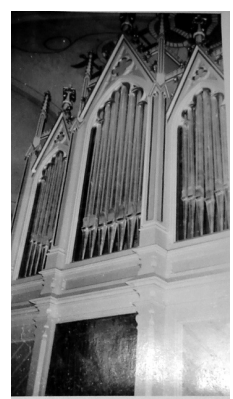

Il. 15. Prospekt organów w Górze Ropczyckiej w 1971 r. - fot. ADT

${ }^{23}$ Vollständiges Verzeichnis der seit Gründung des Etablissements (1873) neubauten Orgelwerke, [Krnov 1924], s. 10.

${ }^{24}$ Pasternak, Kierunki stylistyczne, s. 398-401. 


\subsection{Ochotnica Górna}

Woj. małopolskie, pow. Nowy Targ

Dekanat Krościenko

Pierwsze i jak na razie jedyne organy $w$ dziejach tutejszej parafii, erygowanej w 1925 r. przy kościele z 1909 r., zbudowała w 1930 r. firma Rieger z Krnova w Czechosłowacji jako swoje 2442. opus. Aby pomieścić je na chórze tej niewielkiej świątyni, wycięto otwór w jej stropie. Wiemy to dzięki zachowanej fotografii z 1971 r. W latach późniejszych rozebrano stary kościół i wybudowano nowy, do którego Kazimierz Plewa w 1996 r. przeniósł instrument. Pozwoliło to na lepsze wyeksponowanie jego walorów architektonicznych i brzmieniowych ${ }^{25}$.

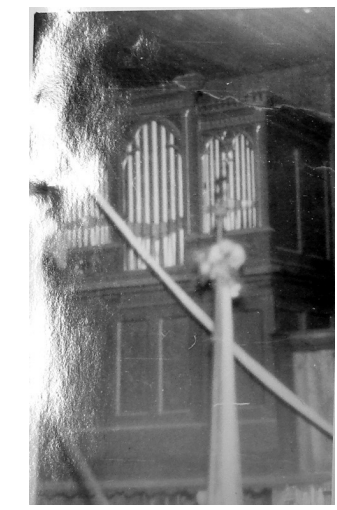

Il. 16. Prospekt organów w Ochotnicy Górnej w 1971 r. - fot. ADT

\subsection{Rytro}

Woj. małopolskie, pow. Nowy Sącz

Diecezja tarnowska, dekanat Piwniczna

Niedługo po utworzeniu parafii i zbudowaniu drewnianego kościoła nabyto używane organy z kościoła Ducha Świętego w Nowym Sączu. Zbudowała je w 1888 r. firma Rieger z Jägerndorfu jako opus 199. Podczas przeniesienia w 1933 r. dodano dwa głosy pedałowe. Po wojnie organy kilkakrotnie przerabiano. Stan z 1971 r. jest uwidoczniony na fotografiach. Organy rozebrano wraz z kościołem na początku lat 80 . Obecnie stoi tam nowa świątynia, w której nie ma organów piszczałkowych ${ }^{26}$.

${ }^{25}$ Pasternak, Organy firmy Rieger z okresu międzywojennego w diecezji tarnowskiej, w: Ślaskie Organy V, red. G. Poźniak, Opole 2017, s. 57.

${ }^{26}$ Pasternak, Organy i ich twórcy, s. 30-31. 


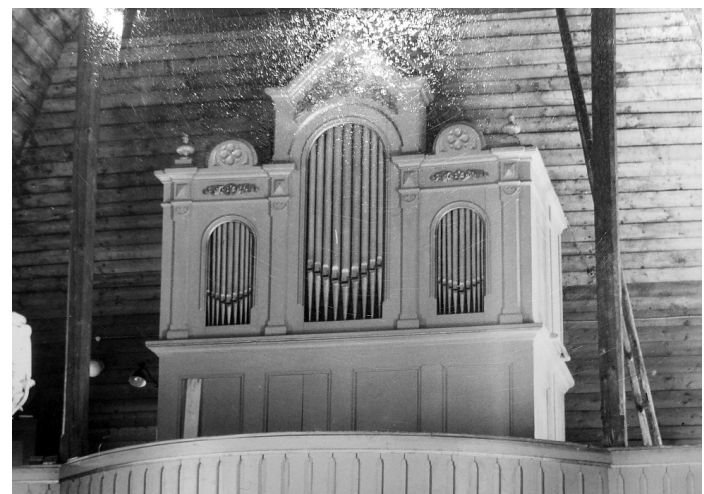

Il. 17. Prospekt organów w Rytrze w 1971 r. - fot. ADT

\subsection{SZczucin}

Woj. małopolskie, pow. Dąbrowa Tarnowska

Diecezja tarnowska, dekanat Szczucin

W 1911 r. firma Rieger zbudowała tutaj nowe organy (opus 1765), lokując je w szafie organowej z poprzedniego instrumentu z $1837 \mathrm{r}$. Miały one czternaście głosów, dwa manuały i pedał oraz trakturę pneumatyczną. Stan zachowania ilustrują fotografie z $1971 \mathrm{r}$. Zaledwie trzy lata później nowy instrument zbudował Tadeusz Rajkowski z Włocławka. Zabytkowy prospekt rozbudowano o segmenty wolnostojących piszczałek. Niewiele wizualnie zmieniła przebudowa z $2017 \mathrm{r}$. autorstwa Mirosława Jakubowskiego z Włocławka ${ }^{27}$.

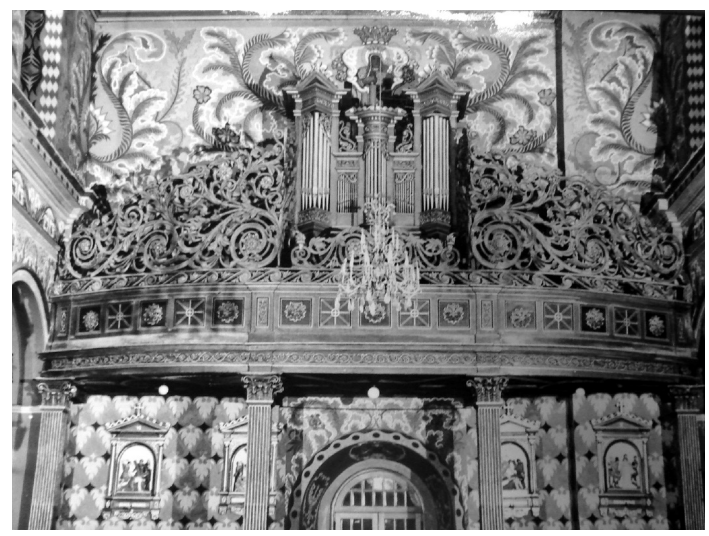

Il. 18. Prospekt organów w Szczucinie w 1971 r. - fot. ADT

\footnotetext{
${ }^{27}$ Pasternak, Tadeusz Rajkowski, s. 73-74.
} 


\section{Antoni Sapalski - Kraków}

\subsection{Czchów}

Woj. małopolskie, pow. Brzesko

Dekanat Czchów

Parafii czchowskiej udało się sprawić organy dopiero w 1853 r. kosztem 770 florenów ${ }^{28}$. Źródła nie wymieniają budowniczego, ale istnieje spore prawdopodobieństwo, że był nim znany krakowski organmistrz Antoni Sapalski. W spisanym z nim kontrakcie na budowę o rok późniejszego instrumentu w kościele Niepokalanego Poczęcia NMP (zwanym kościołem św. Łazarza) w Krakowie zapisano, że „Struktura ma bydź zrobiona według planu do parafii Czechów”29, a tak właśnie dawniej zapisywano nazwę Czchowa. Niestety nie jesteśmy w stanie zweryfikować, czy czchowski prospekt był rzeczywiście podobny do tego u św. Łazarza, ponieważ nie dysponujemy jego fotografią. W archiwum diecezjalnym w Tarnowie zachowała się jedynie niezbyt wyraźna fotografia stołu gry, podobnego do tego w innych dziełach Sapalskiego.

Instrument był kilkukrotnie remontowany, choć wydaje się, że jednak nigdy z dobrym skutkiem. Ostatecznie parafia podjęła decyzję o budowie nowych organów, które wykonał Włodzimierz Truszczyński w latach 1992-1993. Organy Sapalskiego przeniesiono zaś w 1996 r. do nowej parafii w nieodległych Dzierżaninach. Trzy lata później ta sama parafia otrzymała z Janowic drewniany kościół z wyposażeniem, do którego zaliczały się również organy, prawdopodobnie przeniesione $\mathrm{z}$ klasztoru reformatów w Zakliczynie ${ }^{30}$. Byłoby to zatem dzieło Jana Grocholskiego o ośmiu głosach (sześć w manuale i dwa w pedale) z $1888 \mathrm{r}^{31}$ Organy te w barbarzyński sposób połączono z tymi z Czchowa. Takie połączenie oczywiście nie mogło trwale funkcjonować, więc sklecony w ten sposób instrument również miał krótki żywot. W latach 2016-2017 Mirosław Jakubowski dokonał przebudowy i rekompozycji nadających się do wykorzystania części, W wyniku czego powstał ośmiogłosowy instrument $\mathrm{z}$ jednym manuałem i pedałem. Autorowi udało się przed ostatecznym demontażem zobaczyć i sfotografować pozostałości dawnych organów, w tym domniemanego dzieła Sapalskiego z Czchowa.

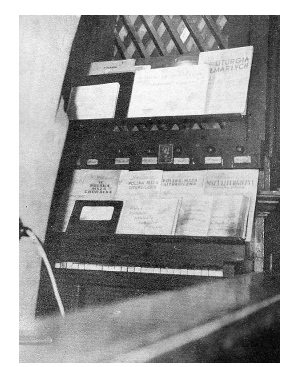

Il. 19. Stół gry organów w Czchowie w 1971 r. - fot. ADT

\footnotetext{
${ }^{28}$ ADT, sygn. ARz 119, ADO Czchów z $1971 \mathrm{r}$.

${ }^{29}$ Archiwum Sióstr Miłosierdzia w Krakowie, sygn. AD 157, Kontrakt z 23 VIII 1854, s. nlb.

${ }^{30}$ ADT, sygn. ARz 119, ADO Janowice z $1971 \mathrm{r}$.

${ }^{31}$ „Bonus Pastor” 1888, nr 24, s. 192.
} 


\subsection{Radgoszcz}

Woj. małopolskie, pow. Dąbrowa Tarnowska

Dekanat Dąbrowa Tarnowska

Według ankiety z $1971 \mathrm{r}$. organy miały być sprowadzone około 100 lat wcześniej ze Szczucina. Ankieta ta zawiera także fotografie prospektu, stołu gry i dyspozycję dziesięciogłosowego instrumentu ${ }^{32}$. Zaledwie rok po sporządzeniu ankiety nowy instrument zbudował Tadeusz Rajkowski z Włocławka ${ }^{33}$. Dzięki badaniom ks. Jacka Słowika okazało się, że informacja o przeniesieniu ze Szczucina była nieprawdziwa - organy były wykonane specjalnie dla kościoła radgoskiego, zbudował je w 1868 r. Antoni Sapalski z Krakowa, a remontował w 1905 r. Bronisław Markiewicz z Tarnowa ${ }^{34}$. Zatem mimo iż z obiektu nie zostało zupełnie nic, znamy jego w miarę kompletną historię.

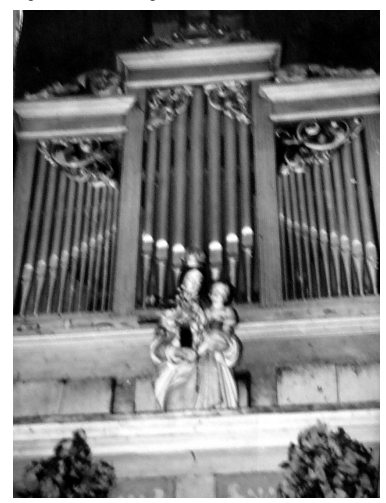

I1. 20. Prospekt organów w Radgoszczy w 1971 r. - fot. ADT

\section{Józef Szymański - Warszawa}

\subsection{Muchówka}

Woj. małopolskie, pow. Bochnia

Dekanat Lipnica Murowana

Pierwsze organy w miejscowym kościele zostały sprowadzone w 1948 r. z kościoła jezuitów w Piotrkowie Trybunalskim. Zbudował je tam Józef Szymański z Warszawy, a inauguracji dokonał August Freyer 14 maja $1871 \mathrm{r}^{35}$ To jeden z najciekawszych importów na teren diecezji tarnowskiej, gdyż Szymański, jako organmistrz z innego zaboru, nie zbudował tu żadnego instrumentu. Na miejscu montował instrument Józef Mrózek z Kisielówki, artysta ludowy i organmistrz-amator. Na podstawie zachowanych zdjęć można wywnioskować, że zmienił on

\footnotetext{
${ }^{32}$ ADT, sygn. ARz 120, ADO Radgoszcz z $1971 \mathrm{r}$.

${ }^{33}$ Pasternak, Tadeusz Rajkowski., s. 71.

${ }^{34}$ J. Słowik, Dzieje parafii w Radgoszczy 1662-1945, Tarnów 2006, s. 137-139.

35 „Kurier Codzienny” 1871, nr 110 (dodatek), s. 3.
} 
stół gry na wolnostojący, charakterystyczny dla swoich dzieł (identyczny z kontuarem w jego nowym instrumencie w Kamionnej). Piszczałki prospektowe były nowsze, wykonane $\mathrm{z}$ cynku, co zapewne jest skutkiem rekwizycji pierwotnych egzemplarzy w czasie I wojny światowej. Organy zostały rozebrane w związku z budową nowych w latach 1983-1985 ${ }^{36}$.

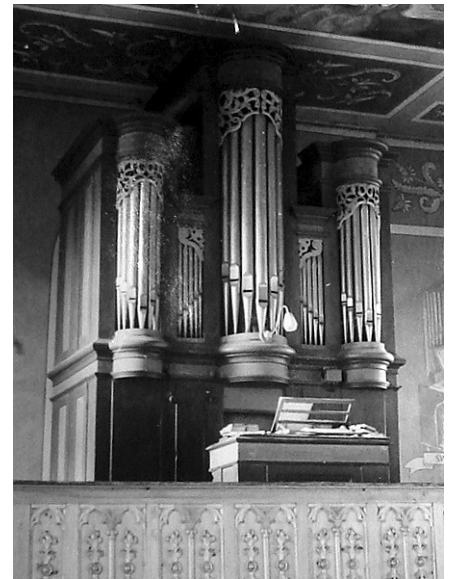

Il. 21. Prospekt organów w Muchówce w 1971 r. - fot. ADT

\section{Jan Śliwiński - Lwów}

\subsection{Grybów}

Woj. małopolskie, pow. Nowy Sącz

Dekanat Grybów

Gdy zbudowano tutaj w latach 1900-1914 monumentalny neogotycki kościół, początkowo przeniesiono do niego organy ze świątyni filialnej pw. św. Bernardyna. Wykonał je Jan Śliwiński ze Lwowa. Na skutek różnych wypadków losowych, jak wojny czy brak funduszy, organy te służyły w kościele aż do 1980 r., kiedy to nowy instrument postawiła firma Włodzimierza Truszczyńskiego. O ich wyglądzie świadczą fotografie w zbiorach ADT. Organy Śliwińskiego miały być przeniesione do nowego kościoła w pobliskiej Kąclowej, co jednak nie doczekało się realizacji. Ostatecznie jedynie niektóre elementy zakupił proboszcz z Jankowej. Piszczałki wewnętrzne zostały zamontowane w tamtejszym instrumencie, natomiast w bocznej kaplicy do dziś znajduje się niewykorzystany fragment prospektu. Jest on bez wątpienia identyczny z prospektem z archiwalnej fotografii. Środkową wieżyczkę zdobi kartusz z inskrypcją następującej treści: „Ks. FRANCISZEK JAWORSKI, proboszcz grybowski, wspólnie z parafianami Organ ten do kościoła Sº Bernardyna i na Jego cześć fundowali R.P.1884"37.

\footnotetext{
${ }^{36}$ Pasternak, Kierunki stylistyczne, s. 430.

${ }^{37}$ P. Pasternak, Nowe organy w Bazylice św. Katarzyny Aleksandryjskiej w Grybowie, „Hosanna”, 11 (2016) nr 1(24), s. 36-38.
} 


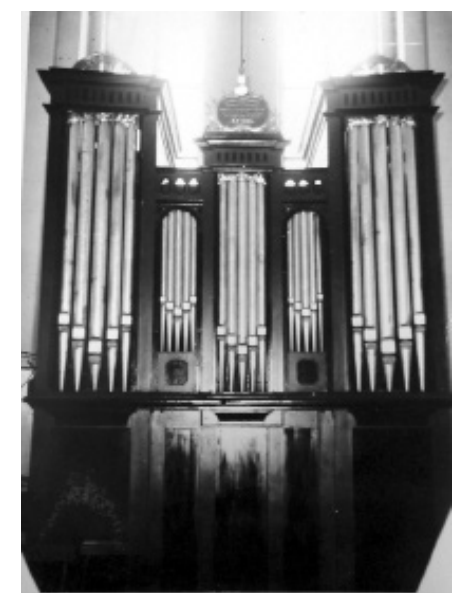

Il. 22. Prospekt organów w Grybowie w 1971 r. - fot. ADT

\section{Kazimierz Żebrowski - Kraków}

\subsection{Tarnów, kościół misjonarzy}

Woj. małopolskie, pow. miejski Tarnów

Diecezja tarnowska, dekanat Tarnów-Południe

Znajdują się tu organy wykonane przez Kazimierza Żebrowskiego z Krakowa w 1911 r. Instrument miał oryginalnie dwadzieścia głosów. Dnia 14 czerwca 1968 r. spisano kosztorys na jego przebudowę. W myśl tego dokumentu Tadeusz Rajkowski zobowiązał się wykonać m.in. przeniesienie sekcji drugiego manuału na boczny chór. Ponadto, o czym nie było mowy w kosztorysie, Rajkowski rozszerzył dyspozycję do dwudziestu pięciu głosów (w tym prawdopodobnie usunął głos Aeolina, wspomniany w protokole odbioru ${ }^{38}$ ), a także zainstalował nowy, wolnostojący stół gry. Rajkowski zakończył swą pracę w 1969 r. Fotografie z 1971 r. uwidaczniają stan instrumentu właśnie po tej przebudowie. Kolejnej przebudowy, podczas której przeniesiono sekcję manuału drugiego z powrotem do szafy organowej, usunięto ze stołu gry włączniki nożne i zmieniono dyspozycję, dokonali w 1993 r. Jan Bryl i Roman Raźniak z Krakowa ${ }^{39}$. Później organy były przerabiane jeszcze dwukrotnie, wobec czego wyglądają dziś całkiem inaczej.

38 „Pogoń” 25 (1911), s. 4.

${ }^{39}$ Pasternak, Tadeusz Rajkowski, s. 102. 


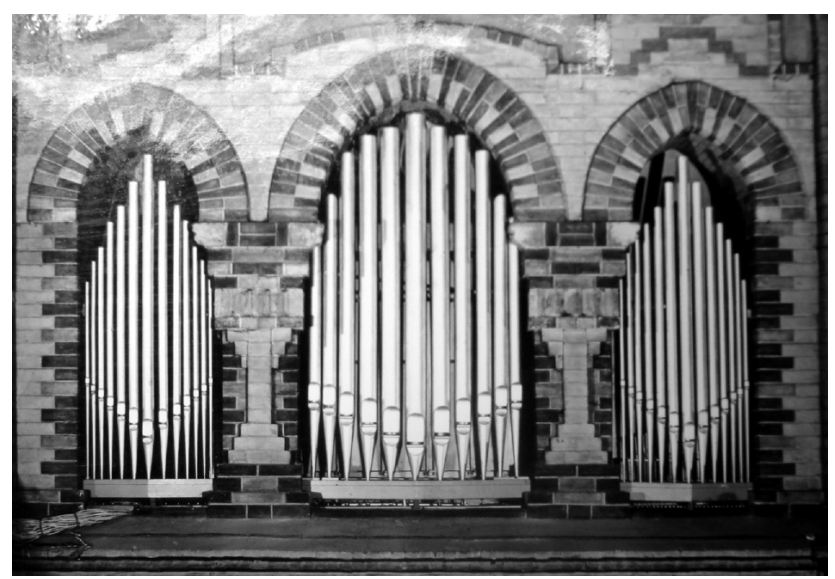

Il. 23. Prospekt sekcji manuału II organów w kościele misjonarzy w Tarnowie w $1971 \mathrm{r}$. - fot. ADT

\section{Organy wykonane po II wojnie światowej}

\subsection{Brzesko-Słotwina}

Woj. małopolskie, pow. i gm. Brzesko

Dekanat Brzesko

W 1944 r. stanęła tutaj drewniana kaplica dająca początek obecnej parafii. Dla tej właśnie kaplicy w 1962 r. firma Wacława Biernackiego z Krakowa zbudowała dziewięciogłosowe organy. Był to instrument niewątpliwie tymczasowy, dysponowany być może z myślą o przyszłej rozbudowie. Jego dyspozycję znamy $\mathrm{z}$ ankiety dotyczącej organów, a wygląd $-\mathrm{z}$ dołączonej do tej ankiety fotografii ${ }^{40}$.

W latach 70. i 80. prowadzono przy świątyni prace, które - chociaż formalnie były jej rozbudową - de facto przerodziły się w budowę nowego, istniejącego do dziś kościoła. W latach 1984-1985 Stanisław Bałchan z Bielska-Białej, notabene były pracownik firmy Biernackich, przeniósł organy do nowego wnętrza, dokonując ich rozbudowy oraz wymiany prospektu ${ }^{41}$. W ten sposób całkowicie zmienił się wygląd zewnętrzny i cechy techniczno-brzmieniowe instrumentu, a o jego pierwotnym kształcie świadczą jedynie archiwalia.

\footnotetext{
${ }^{40}$ ADT, sygn. ARz 119, ADO Brzesko-Słotwina z $1971 \mathrm{r}$.

${ }^{41}$ Pasternak, Kierunki stylistyczne, s. 322-325.
} 


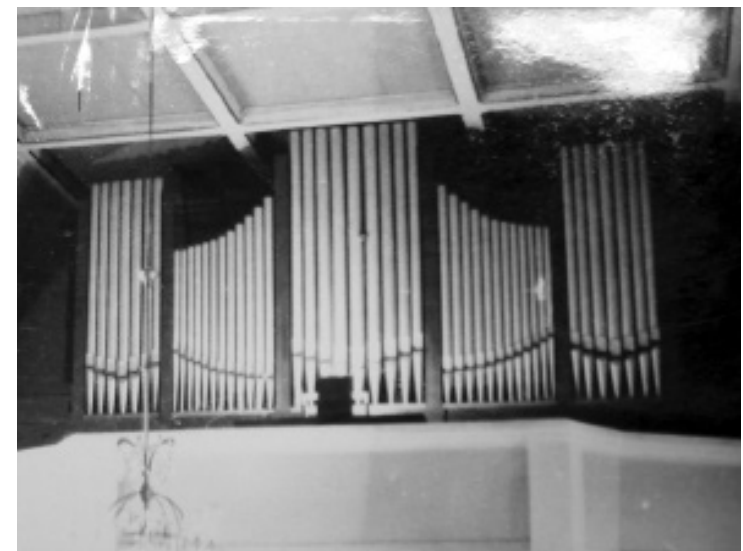

Il. 24. Prospekt organów w Brzesku-Słotwinie w 1971 r. - fot. ADT

\subsection{Moszczenica}

Woj. małopolskie, pow. Gorlice

Dekanat Łużna

W 1963 r. firma Wacława Biernackiego z Krakowa wykonała nowe organy dla tutejszego kościoła. Na fotografiach z $1971 \mathrm{r}$. widoczne są one jako niemal całkowicie nowy instrument ${ }^{42}$. Jednak w latach 80 . powstał nowy, większy kościół i przeniesiono do niego większość nabożeństw. Stan organów w starym kościele uległ wówczas drastycznemu pogorszeniu. Wreszcie w 2004 r. zostały one rozebrane, a części złożono w parafialnym budynku gospodarczym. Wspomniane fotografie są zatem chyba jedynym świadectwem ich pierwotnego wyglądu.

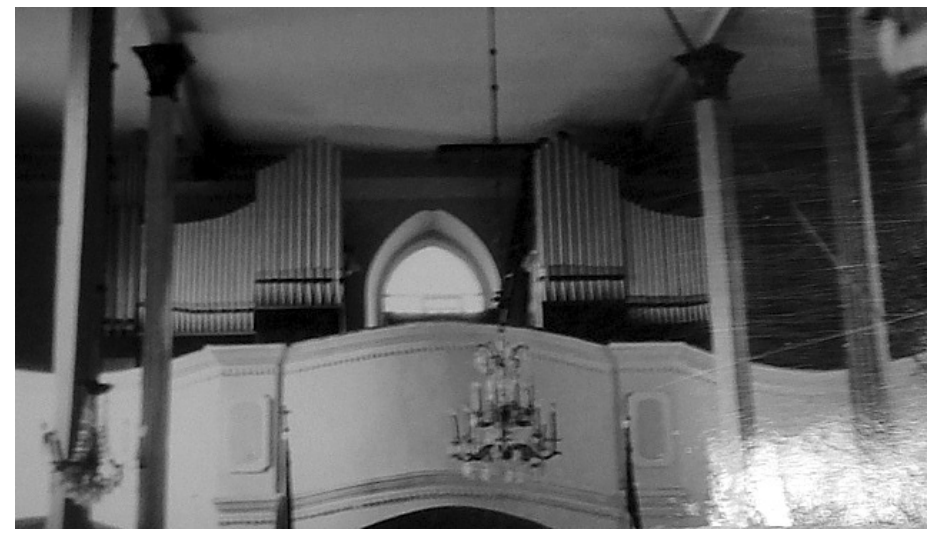

Il. 25. Prospekt organów w Moszczenicy w 1971 r. - fot. ADT

${ }^{42}$ ADT, sygn. ARz 119, ADO Moszczenica z 1971 r. 


\subsection{Tarnów, kościól filipinów}

Woj. małopolskie, pow. miejski Tarnów

Diecezja tarnowska, dekanat Tarnów-Południe

Organy zbudował Wacław Biernacki z Krakowa w latach 1947-1950. Pierwotnie miały osiemnaście głosów, dwa manuały i pedał oraz trakturę pneumatyczną. W takim stanie widoczne są na fotografiach z $1971 \mathrm{r}$. W latach 19781982 zostały rozbudowane przez Stanisława Wilewskiego z Nockowej. W wyniku czego zwiększono liczbę głosów do dwudziestu pięciu. Przerobiono również prospekt, przez co zmieniony został ich wygląd zewnętrzny ${ }^{43}$.

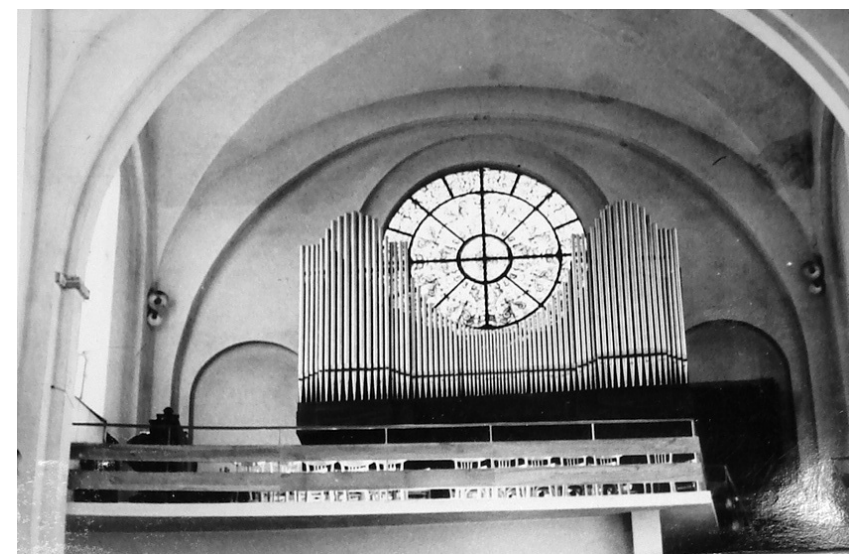

Il. 26. Prospekt organów w kościele filipinów w Tarnowie w 1971 r. - fot. ADT

\subsection{Trzęsówka}

Woj. podkarpackie, pow. Kolbuszowa

Od 1992 r. diecezja rzeszowska, dekanat Kolbuszowa-Zachód

Poprzednie organy kościoła uległy zniszczeniu w czasie II wojny światowej, w 1959 r. wydano więc zalecenie: „Nie ma organów[,] starać się powoli o sprawienie nowych". W następnym roku piętnastogłosowe dzieło wystawił Wacław Biernacki z Krakowa. Na zdjęciach z 1971 r. widzimy instrument tak, jak był pierwotnie zainstalowany w starym, drewnianym kościele. W 2008 r. organy przeniesiono ze starego do nowego kościoła. Wykonano wtedy nowy prospekt. Dyspozycję zmieniono i rozszerzono z piętnastu do osiemnastu głosów. Prace wykonał Grzegorz Stawowy z Woli Baranowskiej ${ }^{44}$.

\footnotetext{
${ }^{43}$ Pasternak, Kierunki stylistyczne, s. 22-24, 425-428.

${ }^{44}$ Tamże, s. 79-82.
} 


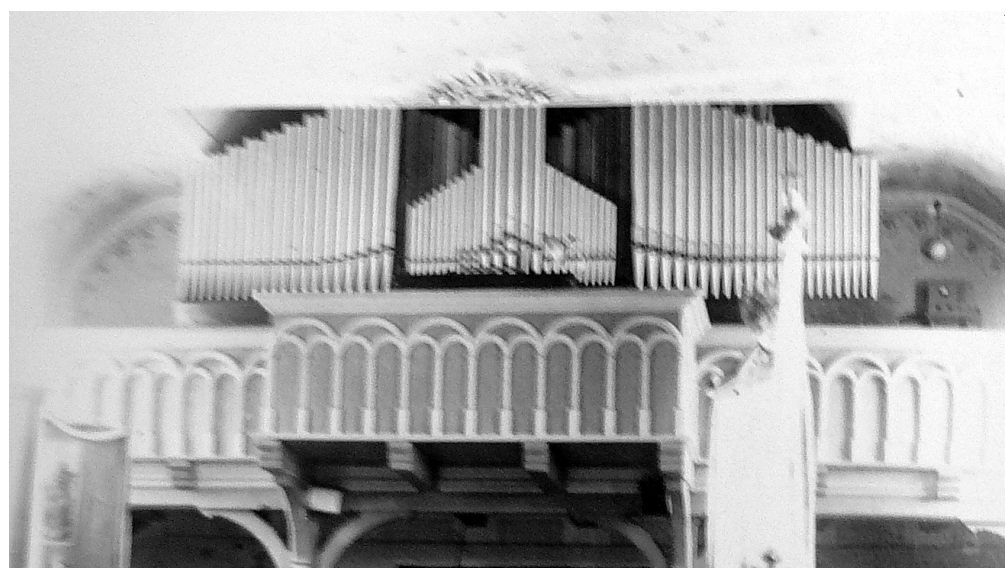

Il. 27. Prospekt organów w Trzęsówce w 1971 r. - fot. ADT

\section{Zaproszenia na inaugurację organów}

Poza dołączonymi do ankiet fotografiami organów ważnymi dokumentami zachowanymi w tarnowskim archiwum diecezjalnym są zaproszenia na poświęcenia organów lub pamiątki takich wydarzeń. Niejednokrotnie są one jedynym świadectwem, na podstawie którego można wnioskować o dacie budowy instrumentu, a także o jego pierwotnym wyglądzie, jeśli był później zmieniany. Do odnośnych ankiet dołączono zaproszenia na poświęcenia organów w Biesiadkach (organy Wacława Biernackiego z 1962 r.), Radomyślu Wielkim (organy Wacława Biernackiego z 1959 r.) i Starym Sączu (organy Tadeusza Rajkowskiego z 1966 r.).

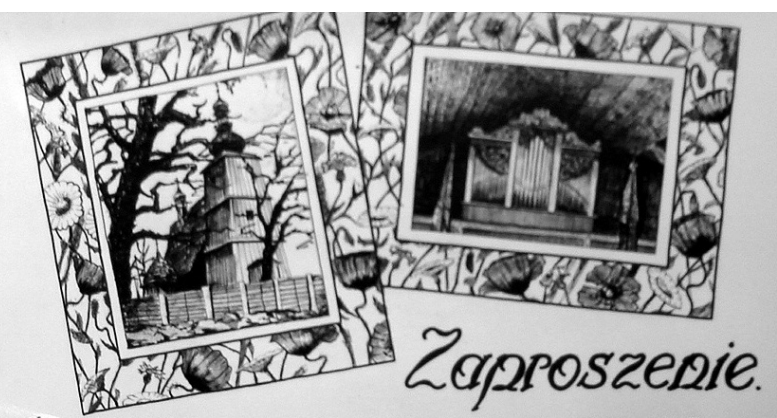

Dnia 19.VIIII962 o godz. 10 30 J.Ex. Ks. Bp Dr. Karol Pe Kala dokona posinięcenia organom no kosciele parafialnym WD Biesiadkach - na kfora to uroczystosic MPP uprzejpare ZQPTQSZO Rada Parafiala

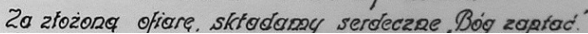

Il. 28. Zaproszenie na poświęcenie organów w Biesiadkach z 1962 r. - fot. ADT 


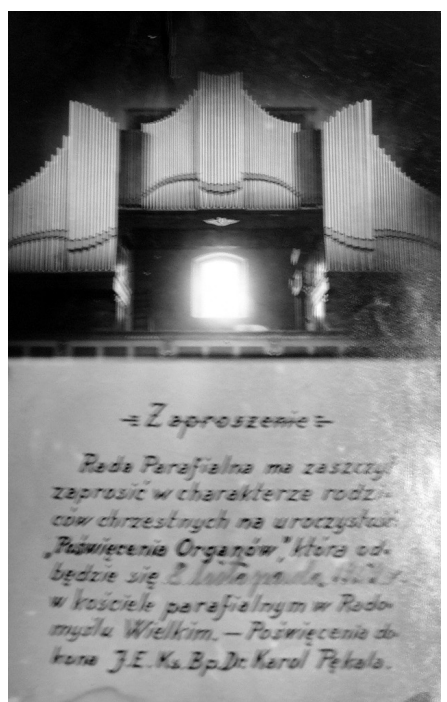

Il. 29. Zaproszenie na poświęcenie organów w Radomyślu Wielkim z 1959 r. - fot. ADT

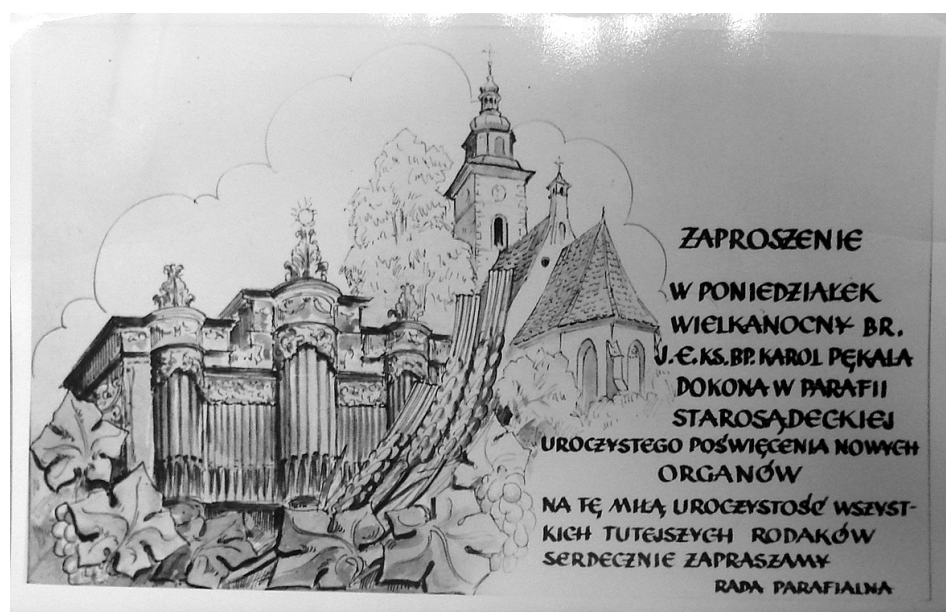

Il. 30. Zaproszenie na poświęcenie organów w Starym Sączu - fot. ADT

Niestety, to ostatnie nie zawiera daty rocznej, lecz z innych wiadomych faktów można wywnioskować, że był to $1966 \mathrm{r}$. Z kolei w dziale fotograficznym znajdują się pamiątki poświęcenia instrumentów w Łęgu Tarnowskim ${ }^{45}$ (sygn. DF II/1383; organy Wacława Biernackiego z 1954 r.) i Łukowej (sygn. DF II/1387; organy Wacława Biernackiego z 1957 r.).

${ }^{45}$ Do 1960 r. parafia ta nosiła nazwę Jurków, dlatego taka też nazwa widnieje na zaproszeniu. 


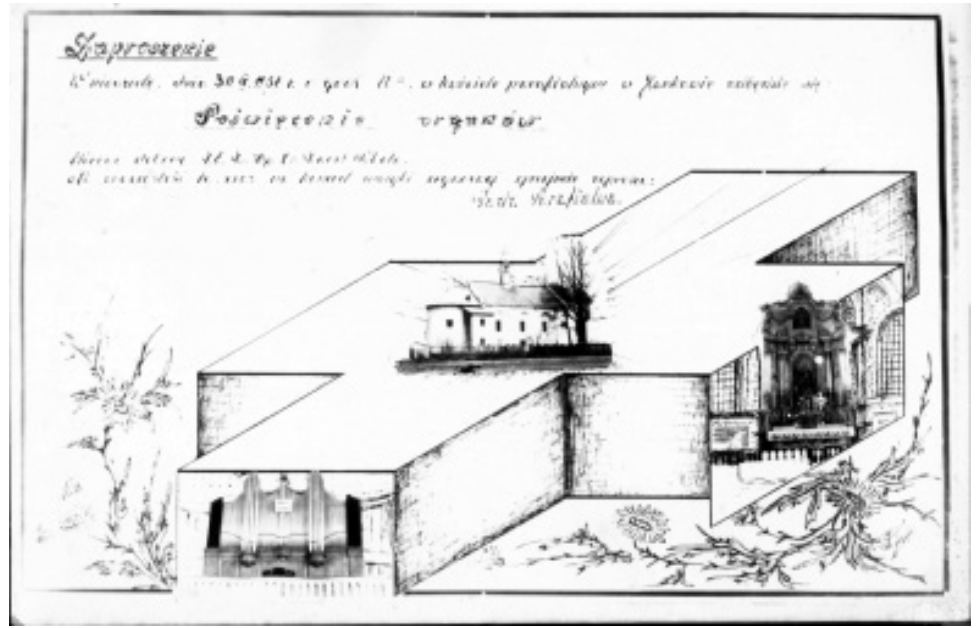

Il. 31. Zaproszenie na poświęcenie organów w Łęgu Tarnowskim z 1956 r. - fot. ADT

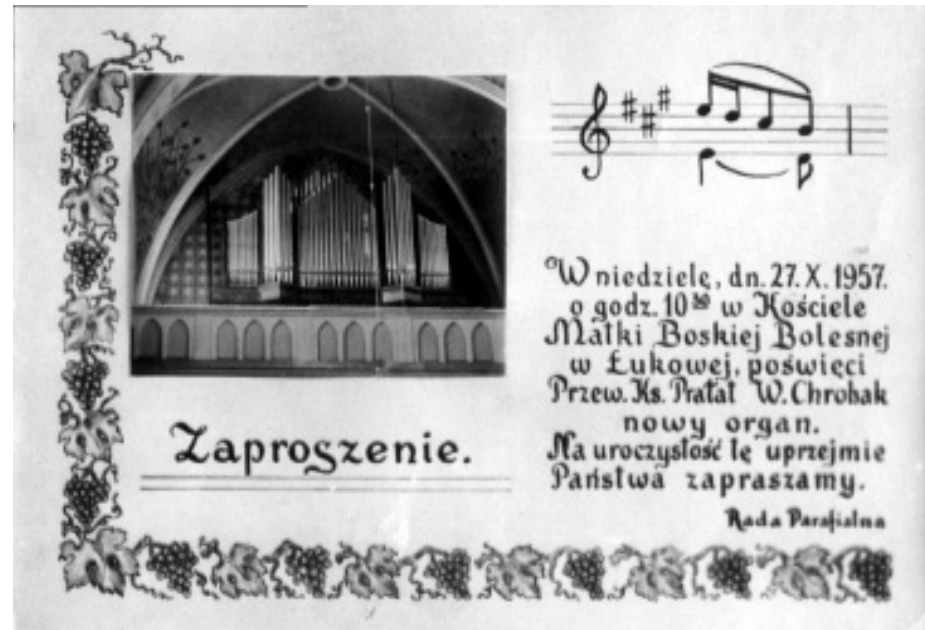

Il. 32. Zaproszenie na poświęcenie organów w Łukowej z 1957 r. - fot. ADT

Zaproszenia tego typu najczęściej przygotowane i rozpowszechniane były amatorskim sposobem. O tym, jak represyjna była komunistyczna władza wobec nawet takich przejawów działalności Kościoła, świadczy kara nałożona w 1962 r. na proboszcza Feliksa Pudełko z Biesiadek za nielegalną dystrybucję zaproszeń [! ${ }^{46}$.

$\mathrm{W}$ ankietach nie zabrakło niestety błędów związanych $\mathrm{z}$ fotografiami organów. W Rzepienniku Biskupim nowe organy zbudował Tadeusz Rajkowski

${ }^{46}$ Ł. Tryba, Rys historyczny organów Wacława Biernackiego w Biesiadkach na podstawie kroniki parafialnej, „Hosanna”, 10 (2015) nr 2(23), s. 40. 
z Włocławka w 1966 r. Fotografia stołu gry przedstawia jednak kontuar z innego instrumentu Rajkowskiego, wykonanego w tym samym roku dla kościoła w Dzierzbicach (obecnie diecezja łowicka). Możliwe są dwa wyjaśnienia tej sytuacji: albo miejscowy proboszcz otrzymał te fotografie od budowniczego, który pomylił instrumenty, lub też stół gry przeznaczony do Dzierzbic czasowo był umieszczony w Rzepienniku. Z kolei ks. Paweł Tyrawski, proboszcz z Łącka, przysyłając fotografię prospektu zaznaczył, że „organy nie posiadają stołu do gry" ${ }^{\prime 47}$, co jest nieporozumieniem, gdyż stół gry jest elementem każdych organów.

Mimo tych niedostatków, fotografie organów zachowane w archiwum diecezjalnym w Tarnowie to fenomenalne źródło do historii organów w tejże diecezji. Zajmując się tym tematem od lat muszę stwierdzić, że od kiedy rozpocząłem korzystanie z archiwum w 2009 r., przeniosły one moją wiedzę o organach w diecezji tarnowskiej na zupełnie inny poziom. Pozostaje tylko ubolewać, że tego typu zbiory nie są w posiadaniu innych archiwów diecezjalnych bądź nie są udostępniane.

\section{REFERENCES / BIBLIOGRAFIA}

\section{Źródła}

Archiwum Diecezjalne w Tarnowie (ADT)

sygn. ARz 119, ankiety dotyczące organów (ADO): Czarna, Czchów, Janowice, Lubzina, Łącko, Moszczenica.

sygn. ARz 120, ankiety dotyczące organów (ADO): Piwniczna, Radgoszcz, Zborowice.

Archiwum Sióstr Miłosierdzia w Krakowie

sygn. AD 157, Kontrakt z 23 VIII 1854, s. nlb.

Archiwum Wydziału Muzyki Kościelnej kurii diecezjalnej w Tarnowie

bez sygn., Protokół przeglądu organów piszczałkowych w parafii Zborowice z 17 kwietnia $2002 \mathrm{r}$.

\section{Prasa}

„Bonus Pastor” 1888, nr 24, s. 192.

„Kurier Codzienny” 1871, nr 110 (dodatek).

„Pogoń” 25 (1911).

\section{Opracowania}

Babnis Maciej, Kultura organowa Galicji ze szczególnym uwzględnieniem działalności organmistrza lwowskiego Jana Śliwińskiego, Słupsk 2012.

Jedynak Andrzej, Parafia wśród lasów, Tarnów 1990.

Kubala Ernest, Organmistrz Tomasz Fall (1860-1922). Życie i twórczość, Kraków 1984 [praca magisterska, Państwowa Wyższa Szkoła Muzyczna w Krakowie].

Pasternak Pawel, Kierunki stylistyczne w budownictwie organowym w diecezji tarnowskiej w latach 1945-1992, t. 2, Warszawa 2021 [praca doktorska, Uniwersytet Muzyczny Fryderyka Chopina w Warszawie].

\footnotetext{
${ }^{47}$ ADT, sygn. ARz 119, ADO Łącko z 1971 r.
} 
Pasternak Paweł, Nowe instrumenty $w$ diecezji tarnowskiej (2017), „Hosanna”, 13 (2018) nr 1(28), s. 28-36.

Pasternak Paweł, Nowe instrumenty $w$ diecezji tarnowskiej (2020), „Hosanna”, 16 (2021) nr 2(35), s. 19-26.

Pasternak Paweł, Nowe organy w Bazylice św. Katarzyny Aleksandryjskiej w Grybowie, „Hosanna”, 11 (2016) nr 1(24), s. 36-38.

Pasternak Paweł, Organy firmy Rieger z okresu międzywojennego w diecezji tarnowskiej, w: Śląskie Organy V, red. G. Poźniak, Opole 2017, s. 47-81.

Pasternak Paweł, Organy i ich twórcy na obszarze ziemi sadeckiej, Nowy Sącz 2018.

Pasternak Pawel, Tadeusz Rajkowski. Działalność organmistrzowska, Opole 2021.

Skorowidz przemystowo-handlowy Królestwa Galicyi, red. J. Olszewski, Lwów 1912.

Słowik Jacek, Dzieje parafii w Radgoszczy 1662-1945, Tarnów 2006.

Tryba Łukasz, Rys historyczny organów Wacława Biernackiego w Biesiadkach na podstawie kroniki parafialnej, „Hosanna”, 10 (2015) nr 2(23), s. 38-42.

Vollständiges Verzeichnis der seit Gründung des Etablissements (1873) neubauten Orgelwerke, [Krnov 1924].

Zwierniak Karol, Organy w parafiach dekanatów Bochnia-Wschód i Bochnia-Zachód. Zarys historyczno-muzyczny, Kraków 2018 [praca magisterska, Uniwersytet Papieski Jana Pawła II w Krakowie].

\title{
THE PHOTOGRAPHS OF THE ORGANS IN THE DIOCESAN ARCHIVES IN TARNÓW AS A SOURCE FOR THE HISTORY OF ORGANS IN THE TARNÓW DIOCESE
}

\begin{abstract}
The photographs of the organs in the Diocesan Archives in Tarnów survived primarily as supplements to the questionnaires of the Centre of the Monuments Documentation from 1971 concerning the state of the organs in parishes. The article discusses the documents which show the instruments that do not exist today and those rebuilt or moved to other churches. In addition to these photographs, the diocesan archives holds invitations to the consecration of five instruments with their photographs.
\end{abstract}

Keywords: archive, organ, organ building, the diocese of Tarnów 